\title{
KUALITAS PELAYANAN PUBLIK BIDANG ADMINISTRASI KEPENDUDUKAN DI DESA TAMBAKSARI KECAMATAN PURWODADI KABUPATEN PASURUAN
}

\author{
${ }^{1}$ Muhammad Saifulloh, ${ }^{2}$ Nur Lailul Fitrotin \\ Jurusan Administrasi Publik, Fakultas IImu Sosial dan Politik, Universitas Yudharta Pasuruan \\ saifulloh94@gmail.com, nur.lailul.fitrotin17@gmail.com \\ PASURUAN JAWA TIMUR - INDONESIA
}

\begin{abstract}
This study aims to determine the quality of public services in the field of population administration in Tambaksari Village. This study uses a qualitative approach with observation, interview, and documentation techniques. The results of the study were measured based on the quality of services in Tambaksari Village. It can be seen by several factors that influence it. The results showed that the quality of public services carried out in population administration services in Tambaksari Village, Purwodadi District, Pasuruan Regency has not been implemented optimally, due to the lack of supporting facilities and other resources in the service process in the field of population administration.
\end{abstract}

Keywords: Public service; Population Administration; Village; Quality

\begin{abstract}
Abstrak
Penelitian ini bertujuan mengetahui kualitas pelayanan publik bidang administrasi kependudukan di Desa Tambaksari. Penelitian ini menggunakan pendekatan kualitatif dengan teknik observasi, wawancara, dan dokumentasi. Hasil penelitian di ukur berdasarkan kualitas pelayanan yang berada di Desa Tambaksari dapat diketahui dengan beberapa faktor-faktor yang mempengaruhinya.

Hasil penelitian menunjukan bawha kualitas pelayanan publik yang dilakukan dalam pelayanan administrasi kependudukan di Desa Tambaksari Kecamatan Purwodadi Kabupaten Pasuruan masih belum terlaksana secara maksimal, disebabkan oleh kurangnya sarana pendukung dan sumberdaya lainnya dalam proses pelayanan bidang administrasi kependudukan.
\end{abstract}

Kata Kunci: Administrasi Kependudukan; Desa; Kualitas; Pelayanan Publik

Open Access at:http://ojs.uho.ac.id/index.php/PUBLICUHO/index

Journal Publicuho is licensed under a Creative Commons Attribution 4.0 International License. 


\section{Journal Publicuho}

ISSN2621-1351 (online), ISSN 2685-0729 (print)

Volume 4 Number 1 (February-April), (2021)pp.90-100

Accredited SINTA SK.NOMOR 28/E/KPT/2019

Open Access at:http://ojs.uho.ac.id/index.php/PUBLICUHO/index

DOI: 10.35817/jpu.v4i1.16235

\section{PENDAHULUAN}

Peran paling penting Pemerintahan dalam menyediakan publik yang prima bagi semua warga negara sesuai yang telah diamanatkan dalam Undang-Undang Dalam pasal 1 Undang -Undang Nomor 25 Tahun 2009 tentang pelayanan publik sebagai berikut:

Pelayanan publik ialah sesuatu kegiatan atau rangkaian kegiatan dalam rangka pemenuhan kebutuhan pelayanan sesuai dengan peraturan perundang-undangan bagi setiap warga negara dan penduduk atas barang, jasa dan atau pelayanan administratif yang disediakan oleh penyelenggara pelayanan publik.

Pelayanan publik ialah suatu rangkaian usaha yang dilakukan kelompok atau seorang birokrasi dalam rangka pemenuhan kebutuhan pelayanan kepada warga negara untuk memberikan bantuan dalam rangka mencapai suatu tujuan tertentu. Salah satu dari pelaksanaan pelayanan publik ialah administrasi kependudukan yang ada di suatu pemerintahan. Administrasi kependudukan adalah rangkaian kegiatan penataan dan penertiban dalam penerbitan dokumen dan data kependudukan melalui pendaftaran penduduk, pencacatan sipil dan pengelolaan informasi penduduk serta pendayagunaan hasilnya untuk pelayanan publik dan pembangunan sektor lain.

Sejalan dengan terlaksananya kebijakan otonomi daerah yang dilaksanaan oleh pemerintah, aparat birokrasi dapat menjalankan pelayanan publik sesuai dengan kebutuhan masyarakat. Prakarsa individu berdasarkan pada aspirasi yang dilakukan kepada masyarakat di daerah tersebut mempunyai konsep yang mendasari dalam hal pengelolahan urusan pemerintah lokal. Otonomi daerah ialah kemauan masyarakat lokal untuk memecahkan berbagai macam permaslahan masyarakat di daerah tersebut untuk mencapai kesejahteraaan masyarakat.

Namun pada ketanyataanya penyelenggaraan pelayanan publik yang di lakukan oleh pemerintah masih dihadapkan dengan ketidak efektifitas dan efisien dalam melakukan pelayanan, serta kualitas sumber daya manusia yang masih kurang memadai. Karena masih banyak pengaduan masyarakat dalam peningkatan kualitas kepuasan pelayanan publik melalui media masa atau pun secara langsung.

Kualitas layanan atau service quality merupakan ketidaksesuaian antara harapan sebuah layanan dengan kinerja. Oleh karena itu peningkatan kualitas pelayanan publik itu sangat penting. Karena disatu sisi tuntunan masyarakat terhadap kualitas pelayanan semakin besar sementara penyelenggaraan pelayanan tidak mengalami perubahan yang berarti. Pada kenyataannya dalam pelayanan publik yang di butuhkan oleh masyarakat masih mengalami hambatan seperti prosesnya yang masih berbeli-belit, lambat, mahal, dan melelahkan, sehingga masyarakat menuntut pelayanan publik yang berkualitas. 
Pemenuhan pelayanan publik perlu memperhatikan kebutuhan pelanggan, pelayanan publik sudah memenuhi kebetuhan pelanggan jika pelayanan publik dapat memberikan pelayanan yang baik berdasarkan teori yang di kemukakan Gasperz dalam Aziz Sanapiah (2000: 15) bahwa kepastian waktu pelayanan, akurasi pelayanan, kesopanan dan keramahan, tanggung jawab, kelengkapan, dan kemudahan mendapatkan pelayanan. Jika pelayanan yang di berikan sudah memenuhi kriteria tersebut, maka dapat dikatakan kebutuhan telah terpenuhi sehingga tercapainya kepuasan pelayanan kepada msyarakat. Sebagai penyedia pelayana kepada masyarakat pemerintah harus terus bertanggung jawab dan terus berupaya untuk memberikan pelayanan terbaik untuk peningakatan pelayanan publik. Tolak ukur dari keberhasilan pelayanan publik dilihat dari tingkat kepuasan masyarakat yang diberikan oleh penyedia pelayanan, oleh karenaa itu pelayanan publikharus di fokuskan pada pemenuhan kebutuhan masyarakat secara maksimal baik dari segi kualitas maupun kuantitasnya.

Berdasarkan Keputusan Menteri Pendayagunaan Aparatur Negara Nomor 63 Tahun 2003 tentang pedoman umum penyelenggaraan pelayanan publik seperti prosedur pelayanan, persyaratan pelayanan, kemampuan petugas pelayanan, kecepatan pelayanan, keadilan mendapatkan pelayanan, kepastian biaya pelayanan, dan kepastian pelayanan, keadilan mendapatkan pelayanan, kepastian biaya pelayanan, dan kepastian jadwal pelayanan maka konsekuansi pemerintah untuk meningkatkan pelayanan dan sektor pelayanan publik. Di harapkan aparat pemerintahan di seluruh Indonesia dapat melaksanakan pelayanan publik dengan baik sesuai apa yang di harapakan oleh masyarakat. Dan juga masih banyak yang harus diperiksa kembali dari pelayanan publik di Indonesia dan juga khususnya di wilayah Desa Tambaksari Kecamatan Purwodadi yang menjadi salah satu dari pelaksana dari pelayanan publik.

Desa Tambaksari merupakan salah satu desa di Kecamatan Purwodadi Kabupaten Pasuruan yang melakukan pelayanan dibidang administrasi kependudukan. Pelayanan publik bidang administrasi kependudukan di Desa Tambaksari meliputi pembuatan surat pengantar Kartu Keluarga (KK), Kartu Tanda Penduduk Elektronik (e-KTP), akta kelahiran, akta pernikahan, akta tanah dan ada pelayanan yang di rekomendasikan seperti surat keterangan ijin usaha.

Berdasarkan pengamatan awal yang telah di lakukan di Desa Tambaksari bahwa terdapat beberapa permasalahn mengenai kualitas pelayanan publik bidang administrasi kependudukan. Masalah yang ditemui saat masyarakat ingin membuat produk dari administrasi kependudukan masih banyak masyarakat yang belum paham dengan persyaratan apa saja yang di butuhkan dan harus dibawa. Dapat ditunjukkan dari masih banyaknya masyarakat yang belum lengkap membawa persyaratan dalam pembuatan surat pengantar yang dibutuhkan. Kurang lengkapnya persyaratan tersebut dikarenakan 


\section{Journal Publicuho}

ISSN2621-1351 (online), ISSN 2685-0729 (print)

Volume 4 Number 1 (February-April), (2021)pp.90-100

Accredited SINTA SK.NOMOR 28/E/KPT/2019

Open Access at:http://ojs.uho.ac.id/index.php/PUBLICUHO/index

DOI: 10.35817/jpu.v4i1.16235

kurangnya informasi dari pihak perangkat desa mengenai persyaratan tersebut. Secara tidak langsung masalah tersebut akan menghambat proses pembuatan KK, e-KTP maupun yang lainnya. Sehingga akan berpengaruh pada lamanya pembuatan KK, e-KTP atau yang lainnya yang masih bisa dilakukan di Kecamatan sehingga akan berdampak pada kepuasan pelayanan yang diterima oleh masyarakat.

Permasalah lain di Desa Tambaksari dalam pelayanan publik di administrasi kependudukan di Desa Tambaksari, yaitu terkait dengan sarana dan prasarana yang belum memedai baik sarana oprasional, fasilitas fisik, serta prasarana pendukung lainnya. Kurang memadainya tempat tunggu untuk masyarakat yang akan melakukan pelayanan. Hanya terdapat satu set meja kursi yang dapat memuat 6 orang pengunjung sedangkan pada kenyataannya pengunjung yang melaksanakan pelayanan secara bersamaan mencapai 8 orang lebih. Sehingga pada akhirnya tidak sedikit masyarakat yang kelelahan berdiri menunggu giliran untuk dilayani oleh perangkat desa.

Permasalahan yang lain yang di temui mengenai pekerjaan administrasi yang belum terlaksana dengan baik, yaitu penataan arsip diruang pelayanan yang masih belum tertata rapi di dalam almari arsip. Dengan sistem kearsipan yang tidak sesuai dengan prosedur dapat menyulitkan pegawai pelayanan dalam melayani karena dalam pencarian membutuhkan waktu lama karena penataan arsip yang belum benar. Sehingga dalam melayani pelayanan menjadi kurang cepat karena terganggu dengan pencarian arsip yang lama.

Berdasarkan kendala-kendala diatas menggambarkan bahwa pelayanan yang diberikaan penyelenggara pelayanan di Desa Tambaksari belum dapat memberikan kepuasan pelayanan kepada masyarakat. Dengan menjelaskan fungsi dan tugasnya dan memiliki wewenang yang istimewa dan tidak menyalah gunakan wewenang, maka jabatan atau kekuasaan dapat memberikan pelayanan yang baik dan berkualitas sebagai pelayan masyarakat.

\section{METODOLOGI}

Penelitian ini merupakan penelitian deskriptif dengan pendekatan kualitatif. Penelitian ini dipilih karena untuk menyajikan data secara sistematis, faktual, dan akurat mengenai faktafakta yang ada dilapangan. Dengan menggunakan desain penelitian deskriptif dengan pendekatan kualitatif yang bertujuan untuk menggali mengenai fakta mengenai kualitas kualitas pelayanan publik dalam bidang administrasi kependudukan di Desa Tambaksari. Informasi penelitian didasarkan pada pertimbangan bahwa informan penelitian dapat memberikan informasi dan yang selengkap-lengkapnya dan relevan dengan tujuan penelitian. Informan penelitian itu yaitu Kaur Pemerintahan sebagai informan kunci (key informan) yang secara langsung melakukan kegiatan di pelayanan umum, sedangkan 
informan pendukungnya yaitu petugas pelayanan dan beberapa masyarakat yang sedang melakukan pelayanan di Desa Tambaksari Kecamatan Purwodadi Kabupaten Pasuruan.

Teknik analisis data yang digunakan dengan melakukan Observasi atau pengamatan, Wawancara atau interview dan studi dokumen.

\section{HASIL DAN PEMBAHASAN}

\section{Kualitas Penyelenggaraan Pelayanan Publik Bidang Administrasi Kependudukan Menurut} Sondamg P.Siagian (1992:128-129) mengatakan, "teori klasik ilmu administrasi negara mengajarkan bahwa pemerintahan negara pada hakikatnya penyelenggaraan dua jenis fungsi utama, yaitu fungsi pengaturan dan fungsi pelayanan. Fungsi pengaturan biasanya dikaitkan dengan hakikat negara modern sebagai suatu negara hukum (legal stat) sedangkan fungsi pelayanan dikaitkan dengan hakikat negara sebagai suatu negara kesejahteraan (walfare state)." Pelayanan publik ini menjadi bagian kebutuhan setiap masyarakat. Setiap birokrasi publik perlu berupaya untuk memberikan kualitas pelayanan yang terbaik kepada masyarakat pengguna layanan. Menurut Lukman (2000:10) dalam buku yang berjudul Kualitas Pelayanan Publik yaitu "Kualitas pelayanan ada pelayanan yang diberikan kepada pelanggan dengan standart pelayanan yang dibekukan sebagai pedoman dalam pemerian pelayanan". Dalam Pelayanan publik pemerintah dikantor Desa Tambaksari, saat ini dirasakan semakin perlu untuk dibenahi dan ditingkatkan, terlebih dalam era seperti saat ini. Upaya untuk meningkatkan kualitas pelayanan publik yang lebih baik merupakan suatu keharusan yang harus segera dilakukan untuk menciptakan pelyanan lebih efisien, efektif, dan sesuai dengan kebutuhan dan apresiasi masyarakat. Kualitas pelayanan publik bidang administrasi kependudukan dapat dilihat dari beberapa aspek, yaitu:

\section{a. Aspek Bukti Fisik di Bagian Pelayanan Umum seksi Kaur Pemerintahan Desa Tambaksari}

Dalam mewujudkan pelayanan publik yang berkualitas perlu dilakukan perubahan dan perbaikan yang mengarah pada kepuasan masyarakat. Salah satu aspek yang harus diperbaiki dalam meningkatkan kualitas pelayanan yaitu masalah fasilitas pelayanan. Peranan sarana pelayanan sangat penting dan salah satu yang sangat berpengaruh terhadap peningkatan kualitas pelayanan publik karena dengan adanya sarana pelayanan yang memadai dapat membuat pelayanan pada masyarakat dapat lebih memberikan kenyamanan dan kepuasan selama berada diruangan pelayanan.

Berdasarkan hasil peneltian yang dilakukan dalam aspek bukti fisik kantor Desa Tambaksari memeliki luas ruangan $8 \times 6 \mathrm{~m}^{2}$ untuk kapasitas jumlah petugas pelayanan 5 orang. Ruangan pelayanan terdapat meja meja pelyanan, meja kerja, 3 set komputer dan meja kursi satu set untuk masyarakat yang menunnggu pelayanan. Hasil wawancara tentang sarana ruang tunggu pelayanan yang dijelaskan oleh petugas pelayanan bahwa untuk sarana dan 


\section{Journal Publicuho}

ISSN2621-1351 (online), ISSN 2685-0729 (print)

Volume 4 Number 1 (February-April), (2021)pp.90-100

Accredited SINTA SK.NOMOR 28/E/KPT/2019

Open Access at:http://ojs.uho.ac.id/index.php/PUBLICUHO/index

DOI: 10.35817/jpu.v4i1.16235

prasarana masih belum memadai, seperti masih kurangnya ruang tunggu dan ruangan yang masih sangat terbatas. Dan petugas pelayanan masih mengusahakan pengadaan barang namun sampai saat ini masih belum terealisasi.

Dari hasil waawancara dan observasi dapat diketahui bahwa pihak kantor Desa Tambaksari belum memenuhi fasilitas pelayanan yang memadai untuk memberikan pelayanan kepada masyarakat seperti masih sedikitnya kursi ruang tunggu, sarana informasi yang belum tersedia. Fasilitas seperti genset masih belum ada sehingga ketika listrik mati maka proses pelayanan pun juga akan berhenti total yang artinya masyarakat tidak mendapatkan pelayanan.

Dari pernyataan tersebut dapat diketahui bahwa Desa Tambaksari khususnya bagian pelayanan masih perlu adanya peningkatan fasilitas fisik serta kelengkapan sarana dan prasarana yang memadai demi peningkatan pelayanan administrasi kependudukan. Hal tersebut sesuai dengan salah satu perinsip pelayanan yang tercantum dalam Keputusan Mentri Pendayagunaan Aparatur Negara No. 63/KEP/M.PAN/7/2003 yaitu tersedianya sarana dan prasarana kerja dan pendukung lainnya yang memadai termasuk penyediaan sarana teknologi telekomunikasi dan informatika dan UU No. 25 Tahun 2009 di jelaskan bahwa penyediaan fasilitas dan sarana prasarana pelayaan yang memadai oleh penyelenggaraan publik.

\section{b. Aspek keandalan di Bagian Pelayanan Umum Desa Tambaksari.}

Dengan semakin tingginya kebutuhan masyarakat akan pelayanan ini harus diimbangi dengan pelayanan yang maksimal dan cepat yang menuntut aparatur untuk cekatan dalam bekerja. Kanandalan adalah kemampuan memberikan pelayanan yang cepat, akurat dan memuaskan, seperti halnya ketepatan waktu, kecepatan dan kecermatan dalam penyelesaiaan pelayanan. Keandalan juga merupakan dilihat sajauh mana para aparatur dapat secara cepat, tepat dan kecermatan dalam setiap pemberian pelayanan kepada masyarakat.

Kemampuan suatu Kantor Instansi Pemerintahan memberikan jasa untuk memberi pelayanan sebagaimana yang dengan tepat waktu, akurat, dan terpecaya serta salah satu elemen penting yang dimiliki oleh pemberi jasa pelayanan dengan memberikan pelayanan yang sama secara tepat guna.

Berdasarkan hasil observasi dapat disimpulkan bahwa prosedur pebuatan administrasi kependudukan sebenarnya mudah selama persyaratan serta berkas yang dibutuhkan sudah lengkap. Dalam penyelesaiaan administrasi kependudukan lama atau cepatnya juga tergantung pada pemohon sendiri. Hal utama yang sering menimbulkan keterlambatan yaitu kurang lengkapanya berkas yang dibawa oleh pemohon sehingga membutuhkan waktu lebih dalam proses penyelesaiannya. 


\section{c. Aspek daya tanggap di Bagian Pelayanan Umum Desa Tambaksari.}

Responsivitas pegawai pelayanan sangat diperlukan dalam pelayanan publik, hal ini menjadi tindakan nyata dilakukan organisasi dalam menjawab serta mengenali kebutuhan dan aspirasi yang dibutuhkan oleh masyarakat. Daya tanggap dalam hal ini berarti respon atau kesigapan petugas dalam membantu masyarakat yang membutuhkan pelayanan.

Daya tanggap pegawai pelayanan dalam mengahadapi kebutuhan masyarakat dengan membantu menjelaskan kesulitan masyarakat atau kebingungan masyarakat sehingga paham betul dan menjelaskan persyaratan apa saja yang di butuhkan dan kekurangan yang ada untuk dilengkapi. Hal tersebut menunjukkan respon daya tanggap yang diberikan oleh perangkat Desa Tambaksari sesuai dengan apa yang dibutuhkan oleh masyarakat.

\section{d. Aspek jaminan di Bagian Pelayanan Umum Desa Tambaksari}

Sebagai kantor yang berwenang menangani masalah kependudukan khususnya warga Tambaksari, Kantor Desa Tambaksari perlu adanya perbaikan pelayanan untuk memberikan kenyamanan selama pelayanan dilaksanakan dan juga memberikan rasa aman bagi masyarakat selama pelayan, baik dilingkungan kantor maupun diluar kantor, agar masyarakat mendapatkan rasa keaman selama pelayanan.

Selain dari jaminan keamanan lingkungan pelayanan, ada juga jaminan yang pasti untuk terhadap pemohon administrasi kependudukan dengan kemampuan yang di berikan pihak instansi terkait, sehingga mereka menkapatkan kepuasan dalam pelayanan. Kompetensi petugas pemberi pelayanan publik harus dengan tepat berdasarkan pengetahuan, keahlian, keterampilan, sikap dan pelaku yang dibutuhkan. Petugas pelayanan di Desa Tambaksari telah berusaha semaksimal mungkin untuk melaksanakan tugas dengan baik proses berlangsung, supaya ketika ada keluhan dari masyarakat agar segera ditindak lanjuti. Penyelenggaraan pelayanan di Bagian Pelayanan di Desa Tambaksari dilakukan dengan mengusahakan agar dapat terselenggara secara efektif dan efisien. Oleh karena itu baik masyarakat yang menerima layanan maupun petugas yang memberikan pelayanan harus memahami prosedur yang berlaku.

\section{e. Aspek empati di Bagian Pelayanan Umum Desa Tambaksari}

Empati merupakan rasa peduli untuk memberikan perhatian kepada masyarakat terhadap kebutuhan yang sedang membutuhkan pelayanan. Sebagai instansi publik yang memberikan pelayanan dituntut untuk selalu siap dalam membantu masyarakat yang membutuhkan pelayanan. Kepedulian pegawai untuk selalu mengutamakan kebutuhan masyarakat akan mendukung terciptanya kualitas pelayanan publik. Sikap empati atau kepedulian yag di tunjukkan oleh masyrakat yaitu dengan menjelaskan secara jelas dan lugas supaya pelayanan dapat diterima dengan baik oleh masyarakat dan juga menerima kritik dan saran dengan sepenuh hati untuk evaluasi terhadap pelayanan yang lebih baik. 


\section{Journal Publicuho}

ISSN2621-1351 (online), ISSN 2685-0729 (print)

Volume 4 Number 1 (February-April), (2021)pp.90-100

Accredited SINTA SK.NOMOR 28/E/KPT/2019

Open Access at:http://ojs.uho.ac.id/index.php/PUBLICUHO/index

DOI: 10.35817/jpu.v4i1.16235

Petugas pelayanan dalam melayani masyarakat dalam penguusan terkait dengan urusan administrasi kependudukan sudah cukup baik. Pemeberian pelayanan kesediaan aparat dalam memberikan informasi merupakan hal yang perlu diperhatikan. Kesediaan pegawai dalam memberikan informasi terhadap masyarakat yang membutuhkan pelayanan akan dapat memperbaiki cara pelayanan dimata masyarakat. Sehingga dalam menciptakan pelayanan prima masyarakat perlu didukung dengan adanya pegawai yang berempati dalam membantu kebutuhan masyarakat yang membutuhkan informasi.

\section{Kendala dalam Meningkatkan Kualitas Pelayanan Publik di Desa Tambaksari.}

Dalam melaksanakan tugasnya sebagai pelayanan umum. Desa Tambaksari mengalami beberapa permaslahan dalam proses penyelenggaraan pelayanan publiknya, Berdasarkan hasil wawancara saat melaksanakan observasi di bagian pelayanan umum memberikan informasi bahwa dalam pelayanan administrasi pegawai pelayanan di Desa Tambaksari, yang terdiri dari 5 pegawai, tetapi kenyataannya hanya terdapat dua pegawai yang bertugas. Dengan adanya kekurangan pegawai pelayanan ini menyebabkan pegawai merangkap pekerjaan yang lain dan membutuhkan waktu yang lebih untuk menyelesaikan pekerjaan pelayanan yang seharusnya dilaksanakan dengan cepat.

Dalam menilai sukses dan adanya hambatan pada pelayanan dengan mengkaji empat variabel dari kebijakan yang menurut George C. Edward III (dalam Supriadin, R., \& Alam, S. 2020: 71) berpandangan bahwa implementasi kebijakan dipengaruhi oleh empat variabel, yaitu:

1) Komunikasi, yaitu keberhasilan implementasi kebijakan mensyaratkan agar implementor mengetahui apa yang harus dilakukan, dimana yang menjadi tujuan dan sasaran kebijakan harus ditransmisikan kepada kelompok sasaran (target group), sehingga akan mengurangi distorsi implementasi.

2) Sumber daya, meskipun isi kebijakan telah dikomunikasikan secara jelas dan konsisten, tetapi apabila implementor kekurangan sumberdaya untuk melaksanakan, maka implementasi tidak akan berjalan efektif. Sumber daya tersebut dapat berwujud sumber daya manusia, misalnya kompetensi implementor dan sumber daya finansial.

3) Disposisi, adalah watak dan karakteristik yang dimiliki oleh implementor, seperti komitmen, kejujuran, sifat demokratis. Apabila implementor memiliki disposisi yang baik, maka implementor tersebut dapat menjalankan kebijakan dengan baik seperti apa yang diinginkan oleh pembuat kebijakan. Ketika implementor memiliki sikap atau perspektif yang berbeda dengan pembuat kebijakan, maka proses implementasi kebijakan juga menjadi tidak efektif.

4) Struktur Birokrasi, Struktur organisasi yang bertugas mengimplementasikan kebijakan memiliki pengaruh yang signifikan terhadap implementasi kebijakan. Aspek dari struktur 
organisasi adalah Standard Operating Procedure (SOP) dan fragmentasi. Struktur organisasi yang terlalu panjang akan cenderung melemahkan pengawasan dan menimbulkan red-tape, yakni prosedur birokrasi yang rumit dan kompleks, yang menjadikan aktivitas organisasi tidak fleksibel. (Supriadin, R., \& Alam, S. 2020).

Berikut uraian hasil penelitian berdasarkan pendapat George C. Edward III :

\section{a. Komunikasi}

Menurut Agustino (2006:157); "komunikasi merupakan salah-satu variabel penting yang mempengaruhi implementasi kebijakan publik, komunikasi sangat menentukan keberhasilan pencapaian tujuan dari implementasi kebijakan publik". Salah satu faktor yang turut mempengaruhi pelaksanaan tugas pelayanan pemerintah di wilayah Desa Tambaksari adalah faktor kesadaran masyarakat yang mana kesadaran masyarakat untuk mempersiapkan segala yang menjadi persyaratan untuk melakukan urusan pelayanan di kantor Desa Tambaksari. Untuk mencapai tujuan yang diharapkan dari pihak aparat dan masyarakat, perlunya relasi antara aparat pemerintah dengan masyarakat dalam pencapaiaan tujuan yang baik. Dan terjalinnya suatu komunikasi yang baik antara aparatur Desa dengan masyarakat.

\section{b. Sumber Daya Aparatur}

Pada penjelasan yang dikemukakan oleh Edwards III (1980:11) mengkategorikan sumber daya organisasi terdiri dari : "Staff, information, authority, facilities; building, equipment, land and supplies". Edward III (1980:1) mengemukakan bahwa sumber daya tersebut dapat diukur dari aspek kecukupannya yang didalamnya tersirat kesesuaian dan kejelasan; "Insufficient resources will mean that laws will not be enforced, services will not be provided and reasonable regulation will not be developed ". Memberikan pelayanan yang maksimal kepada masyarakat sangat dibutuhkan aparatur pemerintah yang memadai. Jumlah pegawai yang ada di seksi kaur pemerintaahan ada satu orang, yang mana dalam pemberian pelayanan kaur pemerintahan ini di bantu oleh staf yang lain jika sedang berhalangan hadir. Dengan keterbatasan jumlah pegawai dibagian pelayanan umum sehingga dapat menghambat kerja pelayanan publik kepada masyarakat dikarenakan pegawai harus merangkap pekerjaan.

\section{Sarana dan Prasarana (Disposisi)}

Menurut Edward III dalam Wianrno (2005:142-143) mengemukakan "kecenderungankecenderungan atau disposisi merupakan salah-satu faktor yang mempunyai konsekuensi penting bagi implementasi kebijakan yang efektif". Dalam Keadaan sarana dan prasarana penyelenggaraan pelayanaan publik yang belum terpenuhi secara lancar dalam urusan pelayanan yang dilakukan. Belum terpenuhinya tempat pelayanan dengan sarana ruang tunggu dan juga belum ditunjang dengan fasilitas-fasilitas untuk kenyamanan untuk para konsumen pelayanan. Ruang tunggu yang belum sesuai dengan tingkat kedatangan 


\section{Journal Publicuho}

ISSN2621-1351 (online), ISSN 2685-0729 (print)

Volume 4 Number 1 (February-April), (2021)pp.90-100

Accredited SINTA SK.NOMOR 28/E/KPT/2019

Open Access at:http://ojs.uho.ac.id/index.php/PUBLICUHO/index DOI: 10.35817/jpu.v4i1.16235

pengunjung, kurang tersedianya kamar kecil/toilet dan tempat sampah, dan juga staf kebersihan yang masih belum terbentuk.

\section{d. Struktur Birokrasi}

Berdasakan hasil penelitian Edward III yang dirangkum oleh Winarno (2005:152) menjelaskan bahwa: "SOP sangat mungkin dapat menjadi kendala bagi implementasi kebijakan baru yang membutuhkan cara-cara kerja baru atau tipe-tipe personil baru untuk melaksanakan kebijakan-kebijakan. Dengan begitu, semakin besar kebijakan membutuhkan perubahan dalam cara-cara yang lazim dalam suatu organisasi, semakin besar pula probabilitas SOP menghambat implementasi".

Dalam menjalankan tugas sebagai pelayanan pemerintah, aparatur pemerintahan Desa juga mempunyai SOP untuk tertatanya dalam proses pelayanan yang diberikan, dan juga menuntun agar dalam pemberian pelayanan kepada masyarakat bisa berjalan baik dan memuaskan. Pada Aparatur Desa Tambaksari masih belum tertatanya SOP yang ada sehingga masih terjadi tumpang tindih dalam penyelesaian tugas yang ada.

\section{Upaya Mengatasi Permasalahan dalam Meningkatkan Kualitas Penyelenggaraan Pelayanan Publik di Desa Tambaksari.}

Adanya permasalahan dalam meningkatkan kualitas penyelenggaraan pelayan publik seperti yang dijelaskan diatas, dijelaskan untuk memberikan upaya-upaya yang mengatasinya sebagai berikut :

a. Dengan mengadakan program penyuluhan yang di lakukan oleh kepala Dusun kepada masyarakat, untuk membantu menyebarkan dan memahamkan masyarakat mengenai hal-hal yang berkaitan dengan kegiatan pelayanan.

b. Penyelenggaraan pelayanan yang tidak memberatkan dan menyulitkan masyarakat.

c. Meningkatkan profesionalisme terhadap masing-masing pegawai di Desa Tambaksari.

d. Mengajukan pengadaan fasilitas penunjang pelayanan.

\section{KESIMPULAN}

Dari hasil analisis dan pembahasan penelitian dapat disimpulkan bahwa kualitas pelayanan publik Bidang Administrasi Kependudukan di Desa Tambaksari masih banyak yang harus diperbaiki dan dikembangkan, dilihat dari empat aspek kualitas pelayanan publik yang ada tahap proses pelayanan yang dilakukan masih kurang akan pelayanan yang diberikan. Adapun penghambat yang mempengaruhi pada tingkat kepuasan masyarakat yang ada menjelaskan bahwa tingkat kepuasan pelayanan yang di berikan kepada masyarakat masih banyak kekurang, sehingga masyarakat harus bersabar dalam melaksanan pengurusan administrasi kependudukan. Kuarangnya sarana dan prasarana dalam kebutuhan pelayanan juga faktor dimana kualitas pelayanan yang diberikan belum terpenuhi. 


\section{DAFTAR PUSTAKA}

Achmad Batinggi. 1999. Manajerial Pelayanan Umum.Jakarta:Universitas Terbuka

Agus Dwiyanto. 2006. Mewujudkan Good Governance Melayani Publik. Yogyakarta: UGM Press.

Edward C. George, Implementasi Kebijakan. Jakarta: Woord press

H.A.S Moenir. 2002. Manajemen Pelayanan Umun di Indonesia. Jakarta : Bumi Aksara

http://www.e-ktp.com/ Apa dan mengapa e-KTP.diunduh 14 januari 2021. Jam 21.15

\section{https://peraturan.bpk.go.id/28-12-20.19.53pm}

Keputusan Menteri Pendayagunaan Aparatur Negara Nomor 63 Tahun 2003 tentang Pelayanan Publik

Keputusan Mentri Pemberdayagunaan Aparatur Negara No.63/KEP/M.PAN/7/2003. Tentang Pedoman Umum Penyelenggaraan Pelayan Publik.

Lexy J. Maleong. 2007. Metode Penelitian Kualitatif. Bandung. PT. Remaja Rosdakarya.

Saefullah.1999.Konsep dan Metode Pelayanan Umum yang Baik, dalam Jurnal Ilmu Soial dan IImu Politik, Sumedang: FISIP UNPAD

Supriadin, R., \& Alam, S. 2020. IMPLEMENTASI PERATURAN WALIKOTA KENDARI NOMOR 13 TAHUN 2008 TENTANG PENATAAN PEDAGANG KAKI LIMA DI KOTA KENDARI. Journal Publicuho, 3(1), 67-89.

Sondang P Siagian.2000. Pelayanan Publik .Jakarta : Bumi Aksara

Undang-Undang Nomor 25 Tahun 2009 tentang Pelayanan Publik 